\title{
Female EFL teachers: shifting and multiple gender and language-learner identities
}

\section{Identidades de género y estudiantiles de maestras de inglés en fomación}

\author{
María Ximena Rojas \\ Universidad de San Buenaventura \\ Bogotá, Colombia \\ E-mail:mxirojas@usbbog.edu.co
}

Received: 24 - Aug - 11 / Accepted: 11 - May - 12

\begin{abstract}
Gender studies have taken an important role within the academic community, and specifically in the field of second and foreign language learning. In this paper I use a Feminist Poststructuralist Discourse Analysis (FPDA) study to explore how emergent femininities construct gender identities and power relations inside the EFL classroom setting through interaction. I argue that identities are multiple and shifting according to the way individuals position and reposition themselves through discourse(s). In doing so, gender identities can be identified and related to learners' identities in EFL contexts. I chose a Feminist Poststructuralist Discourse Analysis (FPDA) methodology (Baxter, 2003) in order to identify telling cases (Mitchell, 1984) during interactions in which, female adult students from a private university in Bogotá, Colombia make explicit the exercising of power during classroom activities, such as debates (Castañeda- Peña, 2009) and disputes (Toohey, 2001) in foreign language learning. I chose video recordings, transcripts and interviews as instruments to cope with the objectives of the study as well as to accomplish the methodological suggestions. Findings suggest the importance of being aware of the multiplicity of gender identities that may intervene when learning a language and how to deal with more egalitarian discourses and activities during classes that guarantee, to some extent, the empowerment of silent voices.
\end{abstract}

Keywords: Gender, Social Identity, Power, Femininities, Positioning, Discourse, Language Learning. Teacher-education

\section{Resumen}

Los estudios acerca de género han tomado un papel importante en la comunidad académica, y en el campo del aprendizaje de una segunda lengua o lengua extranjera. Es por esto que, en este artículo hago uso de un estudio Feminista Postestructuralista del Discurso (FPDA) para explorar cómo las feminidades emergentes construyen identidades de género y relaciones de poder en un salón de clases de lengua extranjera a través de la interacción. Argumento que las identidades son múltiples y cambiantes de acuerdo a la forma en que los individuos se posicionan y reposicionan a través del(los) discurso(s). En este ejercicio, las identidades de género pueden ser identificadas y relacionadas con las identidades estudiantiles en un contexto dónde el Inglés es una lengua extrajera. Escogí la metodología Femisnista Postestructuralista de Análisis del Discurso (Baxter, 2003) para identificar los casos específicos (Mitchell, 1984) durante la interacción en los cuales, estudiantes mujeres adultas de una universidad privada en Bogotá-Colombia hacen explícito el ejercicio del poder durante las actividades en clase, como los debates (Castañeda-Peña, 2009) y disputas (Toohey, 2001) en el aprendizaje de lengua extrajera.Opté por videograbaciones, transcripciones y entrevistas como instrumentos para hacer frente a los objetivos del estudio así como para llevar a cabo las sugerencias metodológicas. Los resultados sugieren la importancia de ser conscientes de la multiplicidad de identidades de género que pueden intervenir cuando se aprende una lengua y cómo lidiar con discursos y actividades más equitativas durante las clases que garanticen, hasta cierto punto, el empoderamiento de las voces silenciadas.

Palabras clave:Género, Identidad Social, Poder, Feminidades, Posicionamiento, Discurso, Aprendizaje de Lengua. Formación de docentes.

* This research study was developed at the Fundación Universitaria Panamericana during the second semester of 2009. 


\section{Introduction}

During my teaching experience, I have noticed how in different contexts, male and female students have different behaviours, such as being competitive (mostly men) or caring too much about discipline issues or grades (women). My first concern about gender issues arouse when working with adolescents in a Saturday program at a public university. I realized how boys used to participate in class actively while most of the girls remained quiet. At the beginning I thought it was because boys had a better English level than girls, but little by little I realized that also girls had a good level of proficiency. Then I noticed through informal conversations that boys thought they had better English level than girls, and that is why in group activities, they were the ones who participated and were the leaders of the group. In some class discussions, boys made comments about their female partners; they thought they were not capable of doing some activities or taking the exams. In some cases girls preferred not to participate in the activities than answer back to boys' comments. I was not sure if it was because girls did not care about their male partners' opinion or because they felt affected by their comments. In any case, this situation sometimes prevented girls from participating and may be, learning or using the foreign language in class. At the end of that course, I wondered if a similar situation would be experienced by adult male and female students at a university level, or if that "race for showing up" was just particular for male adolescent students.

Then, I had the opportunity of working with a just female-group of students at a university level in the undergraduate program of Early Childhood Education and I started to notice that even among female students there were different behaviors and races for showing up their knowledge as well. This situation caught my attention so I began to find literature that could help me understand, somehow, the way my students were behaving. I found many studies about gender issues when learning a second language which are mentioned later on in this paper, but surprisingly, most of them emphasized on children's second language process and the majority of them were done in different countries, which implied a different socio-cultural context from the Colombian one. That's why, I decided to explore in depth the construction of gender identities and their influence on language learning processes and learners' identities in an English class in a female context at a private university in Bogotá .

\section{Social identity and language learning}

Theories about second language acquisition have tried to explain how the process of learning a language occurs and how it is that individuals are part of this development. Although they have helped and contributed to the field of language teaching, there is still a lack of understanding about the relationship between the learner and the language learning context (Norton, 1995). Although there is recognition of the social and cultural contexts when learning a language, it is still argued that the learner is responsible of his/ her interaction with the second language. Some traditional cognitive theories of second language acquisition have not fully acknowledged how inequitable relations of power may limit the opportunities to practice the target language inside and outside the classroom setting. Furthermore, they have considered learners as unmodified entities, categorizing them into dichotomous relations such as, passive or active, motivated or unmotivated, effective or ineffective communicator, good or poor language learner. These theories have not considered that such personality or affective aspects are also socially constructed through power relations that may also vary according to specific time and spaces or possible coexisting in contradictory ways in a single individual (Norton, 1995). 
That is why, this FPDA study is framed within a social identity theory as a way to explain, to some extent, second language learning. This theory "assumes that power relations play a crucial role in social interactions between language learners and target language speakers" (Norton, 1995, p. 12). It is necessary to look at how learners experience power relations when learning a language, due to the fact that, they permeate participation and interaction in communicative events, which have been considered as important and determinant factors in second language learning (Krashen, 1981; Savignon, 1991). It is also important to highlight the view of identity as changing, shifting and as a site of struggle over time and conditions. Norton (1997) states that "identity refers to how people understand their relationship to the world, how that relationship is constructed across time and space and how people understand their possibilities for the future" (p.410) Having in mind these assumptions, a second language theory needs to conceive language learners as having a complex social identity, which, is constructed through day-to-day interactions and in specific settings and times. A second language theory needs also to recognize language as constitutive of and constituted by language learners' social identities.

\section{Gender and language learning}

Regarding classroom interaction, there are some studies that have been reported the relationship between gender and language learning. They have contributed to the understanding of gender identities and their influence in learning identities and learning processes. However, so far, there have not been studies at the University level within EFL contexts in Colombia

Castañeda-Peña (2008b) shows us how, during a lesson in a kindergarten while doing "classroom races" around literacy tasks, "gender discourses are at stake in the classroom and how these discourses are related to the learner identities of a pin down moments in which the assertion of power is manifested in second language practices" (p. 112). This author found out that while doing literacy practices, communicative styles emerged such as the use of assertive language (self-centred language and commands which is usually attributed to men), as well as the use of mitigated language (othercentred language and use of hedges which is attributed to women) and they were indistinctively used by both boys and girls in his study. He also showed how "within the "teacher approval" discourse there are traces of pathological identity construction of girls as language learner. It was illustrated that it is within the "peer approval" discourse where girls could find, at times, positions in which their femininities are empowered interactionally" (p. 124). Therefore, girls construct themselves and are constructed by their peers as 'being good' at languages.

Francis (1998) in her attempt to explore gender construction in primary school, analyzed a lesson where students have to perform a role play about adult occupations. She found out that "gender category maintenance is evident in the children's constructions, and that because of this, many children presented gender as oppositional (in opposition and opposite) in their interviews" (p. 31). She analysed the data in terms of the scenarios chosen, and whether children took up traditional gender stereotypical occupational roles. In regards to this aspect, the scenarios were chosen most of the times by boys and they chose the hospital and the hotel. Girls had a passive role and were unassertive by simply accepting the last role available or even accepting boys' choice. When boys had to take the role of nurse, for instance, they felt ashamed and they manifested that they did not want to do it because they 
felt that is a women's job. She also has a really interesting point which demonstrates that gender is also a matter of cultural understanding when in her own words claims that "the cultures are constructed through in-gender bounding where children position the genders as opposite and in opposition in order to reinforce their own sense of gender identity. However, these cultures are not fixed, being simply the manifestation of children's different constructions; gender boundaries were frequently crossed or resisted, and gender was only one aspect of children's social constructions" (p. 42).

Gender, gender identities, discourse(s), positioning and power.

During the 1990s feminist, linguistic and post-structuralist approaches came to see gender not as a dichotomy but as multiple. Gender is, therefore, understood under the performative view (Butler, 1990) which implies that gender is enacted when we talk, act, read, write, and it is not merely something that we possess. In Coates' words "gender is never static but is produced actively and in interaction with others every day of our lives... Every time we speak, we have to bring off being a woman or a man" (2004, p. 217.). The performative view opens the possibility of exploring a wide range of femininities and masculinities. Consequently, Johnson (1997) defines femininities and masculinities as "on-going social processes dependent upon systematic restatement" (p. 22). Sunderland and Litosseliti (2002) contribute to this definition by stating that "it can also be seen as one's sense(s) of oneself/selves as woman or man" (p.7). This new perspective of gender identities opens the way to analyze language classroom dynamics, acknowledging that, despite of the fact we always have male or female students, teachers should not expect them to act in the same way at all times, or even worse, stereotype and categorize them as the same type of language learners.
The term discourse was also understood under the social theory perspective. Therefore, and in agreement with Fairclough (1995) and Foucault (1972), discourse is conceived as social practice that includes knowledge about cultural ways of thinking and doing and "a potential and arguably actual agent of social construction" (Sunderland and Litosselitti, 2002, p. 13). In this sense, discourse(s) is(are) both, representational and constitutive. They represent a particular way of thinking and understanding, a particular way of seeing the world, but at the same time, they construct and re-construct realities.

In this line of thought, there are many gendered discourses that have been identified by different researchers, where it is possible to recognize how discourses not only represent gendered social practices, but they also maintain gender representations in a particular community, or re-construct those representations and therefore, new or alternative gendered discourses have emerged. Coates $(1997 ; 2004)$ identified and characterized competing discourses of femininity and masculinity, where it was possible to identify "dominant versions of femininity" characterized by women who are gentle, kind, maternal, concerned about their physical appearance, but at the same time, a "subversive maternal discourse" which asserted that having kids and taking care of them is not something they desired or really liked. In this sense, the image of women as maternal, caring and loving is challenged by women's discourses and therefore, re-constructing gendered social understandings.

Having said this, identity is closely related to discourse and vice versa, due to the fact that it is through and in discourse, where identities emerged. Following Chouliaraki and Fairclough's ideas (1999), identity is seen as a two-way process: the way we speak about us and others (affiliation) and the way we are spoken about (attributions). Both processes occur through linguistic and social representations (discourses) 
never outside them. Considering the relationship between identity and discourse allows me now to bring in the concept of positioning. Positioning theory has been discussed by authors such as Harré and Langenhove (1999) who argued that "positioning can be understood as the discursive construction of personal stories that make a person's actions intelligible and relatively determinate as social acts and within which the members of the conversations have specific locations"(p. 16). However these locations may change and vary according to different situations and contexts that individuals encounter in their daily life. That is why, we can find 'positions' attributed or self-attributed such as powerful or powerless, dominant or submissive, assertive or non-assertive, etc.

During negotiations, power is exercised and this is precisely the last construct I refer to. According to Birr and Lewis (2007) "power is produced and enacted in and through discourse, relationships, activities, spaces, and times by people as they compete for access to and control to resources, tools, identities" (p.17). Following this perspective, power is conceived as a product of interactions, what also suggests that it is not static but it circulates among interactors (Foucault, 1980) who are also negotiating their positions and identities, according to their exercising of power.

As it has been argued in this paper positions, identities and power relations are shifted and multiple and they are constructed and constituted through language. That is why I presented this literature review, in order to contextualize and support my findings about gender identities, positions of power and their relationship to learner identities and language learning.

FPDA as both, theory and methodology of analysis

Feminist Poststructuralist Discourse Analysis (FPDA), fits completely with the performative view of gender explained some lines above since it claims that "individuals are never outside cultural forces or discursive practices but always 'subject' to them. Their identities are determined by a range of 'subject positions' (ways of being), approved by their culture, and made available to them by means of the particular discourses operating within a given discursive context" (Baxter, 2003, p 25). FPDA believes in complexity rather than polarization of subjects of study. It claims that subject positions are complex, shifting and multiply located (Baxter, 2003). In other words, subjects come and go between powerfulness and powerlessness according to different speech events.

As a methodology, the researcher in a FPDA study relies on transcripts of talk or written texts as the main source of data. FPDA also includes in the analysis of data two important principles: polyphony and heteroglossia. The first one aims at providing multiple voices into the research study different from the ones of the participants which are present into the transcripts. The second source of data, heteroglossia, aims at including the minority voices in order to "[make] visible the non-official viewpoint, the marginalized, the silenced and the oppressed from other, more dominant viewpoints... Heteroglossia describes the struggle for the control of signifiers such as "woman" and the process by which discourses compete to fix meaning permanently and irrevocably on behalf of hegemonic interest" (Baxter, 2003, p. 69).

FPDA is a layered approach. This methodology has two moments when analyzing the data. The first one is denotative. To come to grips with this level I use Conversation Analysis (CA) in order to analyze naturally occurring conversations. This level of analysis "aims to give a concrete description of what is going on within a text, such as an extract of spoken discourse, by making close and detailed reference to the verbal 
and non-verbal interactions of the participants. (Baxter, 2003, p. 74). At this level of analysis, I look for turn taking, overlaps, interruptions, and silences, during interactions that describe the interaction itself.

The second moment would be connotative. "[This level] is concerned to demonstrate how speakers are continuously positioned or repositioned by a range of competing discourses pertaining to a given social/ institutional context." (Baxter, 2008, p. 77) This moment of analysis is characterized by an interpretative commentary of the extracts of transcripts and the denotative level, as well as the others sources of data collected (participants' interviews).

As this research study aims at exploring how emergent femininities construct gender identities and power relations inside the EFL classroom setting through interaction, the following research questions were proposed in order to lead this study:

- What types of femininities are reflected through students' discourses in an EFL class?

- What power positions are influenced by gendered discursive practices?

- How do power positions influence on students' learning identities?

\section{Setting}

This FPDA study was carried out in a private university in Bogotá (Colombia). The participants of this study were students from an Advance English level course. They belonged to the undergraduate program in Early Childhood Education and most of them were in $6^{\text {th }}$ semester. The group had students aged between 18-22 years. They belonged to low and mid-low social income. All of them had taken three levels of English previously.

The Advanced English course was composed by seven female students. This particular group captured my attention because instead of looking for the dichotomy gendered identities (male vs. women) I could potentially appreciate a variety of femininities that were at stage in this EFL context.

During the six-month period observation, almost all the classes were video recorded, which accounted for twenty sessions in total. However, this data analysis just focused on the lessons were students could actually interact among themselves through debates and solving problem lesson due to the fact that it is through interaction that students position and negotiate identities (Harré, R. E Langenhove, L. (1999), and those kinds of activities allow students to participate orally in a most freely way. Besides, after reviewing all the transcripts of the sessions, I just concentrated on telling cases (Mitchell, 1984) or significant moments (Baxter, 2003) which was quite frustrating because of the time invested on recording several sessions, transcribing and reading the transcripts, but it was how the data occurred naturally. This might be a limitation of the study but the findings in this study resonate with the one carried out by Castañeda-Peña (2009) which is an assertion in this FPDA study.

\section{The Lesson}

In order to give a wider perspective about the extracts that are presented in this article, I briefly describe a lesson that I have chosen as one of my main sources of data. The transcriptions are just extracts from the one-hour session and are the evidence that I chose to be analyzed. The group is composed by Alexandra (A), Patricia (P), Amelia (AM), Mary (M), Alicia (AL), Katalina (K) and Emily (E) (unreal names). They were told to do the task using L2 but they could also use L1 when necessary. The Teacher is a female and is represented in the transcriptions as $(\mathrm{T})$. In order to cope with ethical issues, a consent form was filled in by the participants where I explained the objectives of the study. 
First debate: are women and men equal at last?

This session was planned to be a debate, where students had to interact and defend their points of view about gender equality or inequality in Colombia and around the world. The topic of the debate was chosen by the teacher and most of the students decided the position they wanted to defend, except Katalina, who had to be in the group that thought that there is equality among men and women. This was because the teacher wanted to have an even group of people against and in favour. Consequences and reasons of this decision are discussed in the conclusions and implications.

\section{Denotative level}

Extract 1 took place at the beginning of the class. Although the debate itself is genderoriented, it was possible to identify gendered discursive practices even in the introductory part of the lesson. In this extract, the teacher was asking her students about what they did during the weekend. Previously Alicia was talking about the activities she did when suddenly Katalina starts this interesting interaction.

\section{Extract 1}

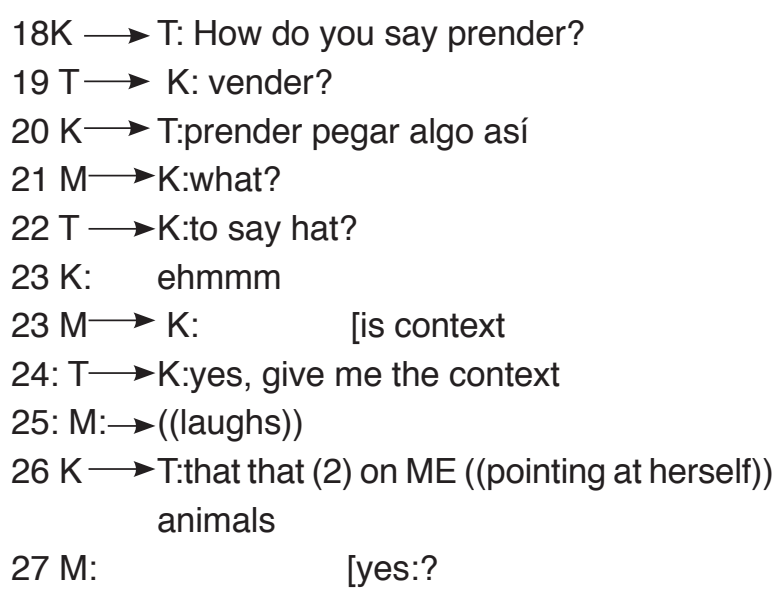

The interaction begins when Katalina asks the teacher to help her with the English word for "prender" (to light). The teacher does not understand Katalina's question and she responds using a one-word question (vender?). Again, Katalina tries to express herself, this time by using Spanish, her native language. In turn 21 Mary intervenes in the interaction by asking Katalina to be clear about what she is talking. It is important to notice that Mary self-selected to speak, nor the teacher neither Katalina who were interacting previously selected her to continue with the interaction. Immediately, the teacher asks Katalina to give her more details in order to understand her original question. While Katalina is trying to rephrase her point, Mary overlaps her asking for the context in which Katalina wants to express herself. Mary is supported by the teacher in turn 24 and Mary laughs. Once more, Katalina tries to convey what she wants to express and is overlapped by Mary with an elongation of "yes:?" what seems to be a tag question, used in order to follow a discourse.

The second extract begins with Katalina's new request for vocabulary. She wanted to understand the word "culture" in her mother tongue.

\section{Extract 2}

$165 \mathrm{~K} \rightarrow \mathrm{T}$ :how do you say culture?

$166 \mathrm{~T} \rightarrow \mathrm{K}$ : culture ((writes the word on the board))

$167 \mathrm{AL} \rightarrow \mathrm{K}:$ how do you mean

$168 \mathrm{M} \rightarrow \mathrm{K}: \quad$ [mean ]

$169 \mathrm{~T} \rightarrow \mathrm{K}:$ what does it mean?

$170 \mathrm{~K} \rightarrow \mathrm{AL}:$ HOW DO YOU SAY

$171 \mathrm{~A} \longrightarrow \mathrm{K}$ : how do you say culture? ((miming and using a different tone of voice)) How=

$172 \mathrm{~K} \rightarrow \mathrm{AL}: \quad$ [ah yes ] $=$ do you mean culture

$173 \mathrm{~K} \rightarrow$ AL: hay:: pero (cuidado me equivoco)

In Extract 2, Katalina starts the interaction by asking the teacher for the meaning of a word. Although she did not use the appropriate expression, it is evident that the teacher wanted to answer 
Katalina's request (turn 166) but immediately Alicia corrects Katalina by giving her what she thought "it is the correct way to express her idea". Alicia is supported by Mary who emphasizes the word "mean". Katalina raises her voice (turn 170) and repeats what she said in turn 165. Alicia repeats Katalina's utterance using this time a tone of voice that simulates a dumb person and once again corrects Katalina who finally accepts her "mistake" and who finishes with a sentence that claims for the right to be wrong in an EFL context.

The third extract shows an interaction between Alexandra, Amelia, Mary and the Teacher. Amelia was previously defending her point of view and Alexandra manifests to have problems trying to understand one word of Amelia's speech.

\section{Extract 3}

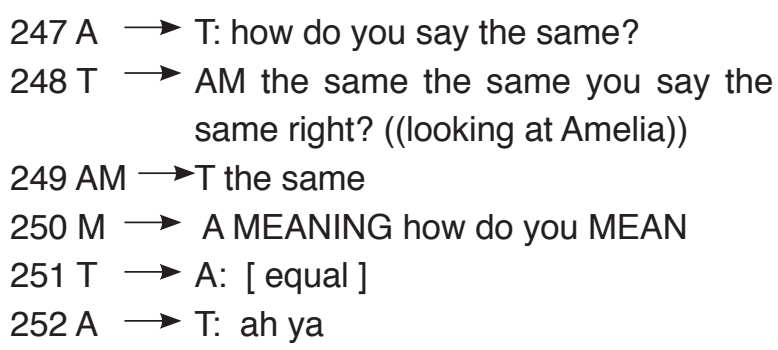

In Extract 3, Alexandra asks for the meaning of the expression "the same". The teacher tries to answer the question by repeating the expression and verifying that it was what Amelia wanted to say. Amelia reinforces the expression and it is Mary who, once again, corrects Alexandra's utterance. The teacher provides a synonym in L2 and finally Alexandra conveys the meaning of the expression.

The teacher-like behaviour (FPDA commentary, connotative level)

How does a teacher behave in a lesson? What are the characteristics of her/his speech? Guiding, correcting, providing feedback, answering students' questions, among others are usually associated with the teachers' job. Walkerdine (1998) reports on a study where teachers describe teacher-type girls or sub-teachers as being bossy, helpful, and as the ones who want to organize other students. In the same line of thought, Orellana (1996) demonstrates how Latino children position themselves as teachers when policing a classmate, in other words, when controlling other's behaviour, or maintaining the discipline in a classroom.

Being a teacher is also considered a powerful position in the classroom setting, due to the idea that the teacher is usually the one in charge of providing opportunities of talking, debating, participating (see Sinclair and Coulthard, 1975 and their study about the interaction among teacher and pupils in the classroom setting). They are usually the ones who nominate students (assign the power for a moment). Teachers are institutionally considered as figures of authority in the sense that they are the ones who approve or disapprove one's speech or participation. All these actions previously described are my understanding of the teacher-like behaviour. During the interactions presented above, it was possible to identify specific moments were two women (Mary and Alicia) manifest a teacherlike behaviour that, allows them to take the floor several times, which could be interpret as showing up their foreign language knowledge or wanting to call attention, but also prevents other students to be more active during the debate. Let us see how it happens in interactions.

In Extract 1, while Katalina is asking for an English word in order to prepare her speech, Mary interrupts her with a solitary "What?" (Turn 21 ). This strategy helps her to take the floor for a while, but more interestingly, she is supported by the teacher who follows the same line of argument that Mary had just used. From an interpretative point of view, it seems that Mary aligns positions with the teacher. Following with the interaction, in turn 23, Mary interrupts once again Katalina's dubitation by asking her to be clearer and 
contextualize her question. For the second time, the teacher reinforces Mary's role of sub-teacher as she pronounces a parallel discourse (Turn 24: yes, give me the context). She also requests a contextual clarification. In turn 25, Mary laughs. What does this laughing mean? A very plausible interpretation leads me to think that after being backed up for the second time by the teacher, it seems that Mary has been empowered and she might be conscious about it. Finally, Katalina tries to contextualize her intervention as she was requested to do it, and Mary overlaps her again with a "yes?", as she was following Katalina's speech as many teachers use to do (Turn 27).

According to the positioning theory, Mary self-positioned as the one who could follow Katalina's speech, by correcting and asking her to be clearer in her speech. Discursively she used strategies that are usually associated with the teachers' role; a discursive practice that was available for her and that was also reinforced by the head-teacher. In terms of gender identities, Mary could re-construct a reality by assuming a different role provided by her assertive femininity, not as a regular student, but as a sub-teacher, which also influence in her identity as an effective English language learner. As she was backed up by the head-teacher, Mary demonstrated that she could actually communicate what she wanted, while Katalina could not. This situation favoured Mary, empowered her and prevented Katalina from expressing herself in the second language, which influenced in her identity as a female student who is not as effective as Mary demonstrated in this extract.

Extract 2, Katalina starts off the interaction by asking for the meaning of the word 'culture'. The teacher wants to answer her question but it is Alicia who behaves as a sub-teacher when she corrects Katalina's utterance (turn 167). Alicia is also supported by Mary who had previously behaved as a sub-teacher. After being scolded and treated as she was inferior or unable to understand, (when Alicia used and mimed a different tone) Katalina realizes about her "mistake" but at the same time she expresses inconformity when she claims her right to be wrong in a learning context. Katalina feels attacked by her classmates, especially by Alicia and Katalina in this interaction. In a post-debate interview she says:

\section{INT-001-K}

Interviewer:

¿cómo te sentiste en el debate?

/How did you feel in the debate?/

Katalina: me sentí atacada por todas, porque es que eran todas

/I felt attacked by everyone, because it was everyone

Interviewer:

¿qué rol jugaste en el debate? /what role did you have in the debate?

Katalina: jugué un rol pasivo

/it was a passive rol/

The teacher- like behaviour experienced by Alicia and Mary in this extract prevented Katalina from participating more in the debate. Discursively, Alicia and Mary made use of strategies such as overlapping and correcting Katalina in order to position themselves, first as teachers (by correcting) and then as students who "know more" about the second language (when overlapping and correcting Katalina in a rude way (turn 171)). Alicia's and Mary's exercising of power when behaving as teachers silenced Katalina's voice who was not given the same opportunities by her peers (Alicia and Mary) to talk in the foreign language. Therefore, Alicia's and Mary's discourses positioned Katalina as a student who need to reinforce her English level, an identity that was attributed. However, Katalina contested that attributed identity when in turn 170 she repeated loudly her previous words (HOW DO 
YOU SAY). For a moment, she questioned the identity she was given (second order positioning). She tried to show that she knew that what she was saying was correct, but Alicia by using the strategy of changing her voice simulating a dumb person (Turn 171), empowered herself once again, up to the point that she made Katalina "realized" about her mistake. At the end of this interaction, Katalina once again contested the position she was attributed by asking for her right to make mistakes as a student of a second language. These conclusions are also supported when I asked Mary and Alicia about the activity in a post-debate interview.

\section{INT-001-M}

Interviewer: ¿cómo te sentiste en el debate? /How did you feel in the debate? /

Mary: me sentí bien /I felt good/

Interviewer: ¿qué rol jugaste en el debate? /what rote di d you have in the debate?

Mary: jugué un rol activo y crítico /it was an active and critical role/

Interviewer: cuando revisamos todas el video, crees que todas siguieron las reglas del debate?

/when we all together checked the video, do you think that all of you followed classroom rules?

Mary: (riéndo) no, fue obvio que yo no levantar la mano es algo que muy pocas veces hago, y respetar lo que ellas decían y tomarlo en cuenta. /(laughing) of course I did not. Raising my hand is something hat I hardly ever do, and respect what they said and take it into account. /

\section{INT-001-A}

Interviewer: ¿cómo te sentiste en el debate? I How did you feel in the debate?
Alicia: Nos sentimos como un trabajo satisfecho. Sentí que era un espacio para demostrarme y notar que sí tenía conocimientos de inglés.

/we felt with a satisfied job. I felt that it was a space to demonstrate and realized that I did have English knowledge.

Finally Extract 3 shows how once again how Mary attempts to correct Alexandra's interventions. Notice that she was constantly paying attention to other students' participations and she uses to overlap them with the purpose of correcting. However, Alexandra's attitude towards Mary's discourse is different from Katalina's. Alexandra ignored her; she was just paying attention to the teacher. She did not intake or repeat Mary's words. It is plausible to say that Mary's discourse was not a sample of solidarity, but she was trying to show off.

Davis (2003), in her study states that "the unanimity of purpose characteristic of the girls' discussion supported the development of a group identity in which similarities among individuals where emphasized whilst, conversely, differences were relegated" (p. 119). Mary's interventions seem to emphasize on the differences rather than on helping others out. Opposite to what Davis found, Mary's discourse relegates other students, especially Katalina, to a lower position. More than solidarity her teacher-like behaviour looked for teacher's attention and recognition. This is a finding in my research that subverts what has been established in the literature.

However, in this particular case, Mary's attempt to position herself in a powerful position was not successfully achieved. Although she was following a storyline (she could positioned herself as a teacher earlier) and she tried to use the same speech act, correcting others (turn 250), the 
social force did not allow her to take a powerful position, due to the fact that the interactors (in this case Alexandra and the head-teacher) just ignored Mary's discourse. In this extract, the head- teacher did not follow Mary's speech, she did not empowered Mary, as she did previously (turns 22 y 24 extract 1 ) when she used a parallel discourse and mutually determined Mary's position as a sub-teacher and therefore as a powerful one. Additionally, Alexandra did not recognize Mary's position either. Opposite to Katalina who in previous turns $(170,172$ extract 2) had acknowledge Alicia's and Mary's discourses, Alexandra just ignored her and could communicate her doubts to the head-teacher, as well as get a response to it.

\section{The lesson}

The following extracts are part of an hoursession class with the same group described previously. The participants in this opportunity are: Patricia (P), Amelia (AM), Mary (M), Alicia (AL), Katalina (K) and Emily (E) (unreal names).

"Survive or not survive, that is the question" lesson

This lesson starts with the teacher's instructions about the tasks that students had to do. Students were told that they are the survivors of an airplane accident and they had certain items that they had to rank in order of their importance to survive. The decisions had to be taken in group. In this opportunity the head- teacher tried to be an outsider, so the interaction that prevailed during this lesson was mainly student-student one.

\section{Extract 4}

$1 \rightarrow$ AM Group: the clothes

$2 \rightarrow$ P Group: ((reading)) the newspaper

$3 \rightarrow$ AM Group: the clothes

$4 \rightarrow$ AL Group: The emmm THE FIRST ( )

$5 \rightarrow \mathrm{E}$ and $\mathrm{M}: \quad$ ((nodding)) map

$6 \rightarrow$ AL Group: SECOND ehhhh
$7 \rightarrow$ AM Group: clothes clothes

$8 \rightarrow$ E Group: ( )

$9 \rightarrow$ AM Group: CLOTHES

$10 \rightarrow$ P AM: an ( ) map plastic no?

$11 \rightarrow M$ and $E$ ye::::S

$12 \rightarrow$ AM P: emmmm yes and second clothes!

$13 \rightarrow T$ Group: remember that you are in extreme conditions of cold (0.2) It's re::ally cold and you will have to wal::k twenty milles

$14 \rightarrow$ AM T: YES teacher

$15 \rightarrow$ AM Group: yes THE CLOTHES

$16 \rightarrow T$ Group: so, remember try to decide

$17 \rightarrow$ AM Group: the clothes the clothes

$18 \rightarrow P \quad$ AL: $(\quad)$

$19 \rightarrow$ AL: ((nods)) map

$20 \rightarrow$ M: map

$21 \rightarrow$ AM M:no::: $(\quad$ ) con un mapa no van a sobrevivir

$22 \rightarrow$ AL AM: pero el mapanossive para llegar

$23 \rightarrow$ AM Group: primero se ponen la ropa y luego cogen el mapa ((laughing))

$24 \rightarrow M$ Group:no::(0.2) primero el mapa y luego la ropa

$25 \rightarrow \mathrm{AL}, \mathrm{P}$ and $\mathrm{M}:(($ whispering $))(\quad)$

$26 \rightarrow E$ Group: yes, sele selectional the map

$27 \rightarrow$ AM Group: ((in low voice)) ummmm yes

\section{Denotative analysis}

In this section, the participants started to decide the order of the items. Patricia held the paper and everybody was looking at it. She read again all the items. Amelia, Alicia, Patricia and Katalina got closer in order to decide the ranking. Amelia wanted the clothes to be the first (Turns 1, 2). However Alicia spoke louder and started by saying "THE FIRST" (turn 4). Everybody paid attention to what she was saying and agreed. Amelia overlapped Alicia and she insisted on the clothes (turn 7). She did not get an answer. Meanwhile, the group was thinking about Alicia's 
suggestion. Amelia insisted again, this time she spoke louder and Patricia was the only one to take her into account. Patricia overlapped Amelia. Patricia asked her about Alicia's suggestion (turn 10). Mary and Emily supported the idea. Amelia agreed; however, she was not convinced and proposed the clothes to be the second (turn 12). The teacher reminded them about the weather conditions and used an extension in the word rea::lly in order to support Amelia's idea. Amelia overlapped her by saying louder "YES TEACHER". Amelia insisted again with the clothes (turn 14, 15). However Patricia and Alicia were taking the decision by themselves and they decided the map to be the first element. Amelia used her mother tongue (Spanish) in order to give Mary the reason why she thought that the map must not be the first element (turn 21). Alicia responded to that reason also in mother tongue and again Amelia insisted on her position by using Spanish once again, but this time she was laughing. Mary insisted on the map by denying Amelia's reason (turn 24). Alicia, Patricia and Emily supported the map election and finally they decided to put in the first place the map. At the end, Amelia consented but she was not convinced.

\section{Determinant femininity (FPDA commentary)}

I gave this name to this type of femininity after analyzing special features in Alicia's interaction. Determinant is understood as having the power or quality of deciding. First of all, she demonstrated leadership during the activity. She positioned herself as the one to be followed. In turn 4, she talked louder and said THE FIRST. This implies that she wanted to be the first one to give her opinion and based on that, her peers started to rank the other elements. She tried to continue by saying THE SECOND. She constantly overlapped Amelia or others in order to express her ideas. According to Schegloff (1997) overlapping and rising intonation are signs of power positioning in discourses. It is evident in this extract that
Alicia's determinant femininity allows her to be the centre of the group, to make decisions or suggest alternatives. She not only proposed an item but also she gave the reason why she thought it should be the first.

\section{Hesitating femininity}

Hesitating is associated with the fact of lacking decisiveness of character, or be unable to act or decide quickly or firmly. This characteristic was shown in Amelia's interactions. Her participations are constantly overlapped and she seemed little or not secure about the things she was saying. For example in turns 1 , 3 , and 7 she insisted on putting the clothes as the most important item. Her participations are not as convincing as Alicia's ones. She uses a lower tone of voice, and she did not give a reason about why clothes should be the first. In turn 12 , she was easily convinced by Patricia about putting the map as the first element and she changed her mind asking the clothes to be the second. She did not argue or defended her position and she only accepted submissively. In turn 21 , she tried to refute Alicia's opinion but she immediately responded with an argument and in turn 23 Amelia tried again to refute but this time she was laughing. Laughing in this case is a proof of hesitation. She was not sure about what she was saying and that is why her peers did not take into account her opinion. To confirm this opinion, I am going to present some extracts from an interview that was carried out individually with each participant. The first one is Patricia's interview and the second one Amelia's

\section{INT-002-P}

Interviewer: Si la prioridad era protegerse del frío, ¿por qué escogieron el mapa como el elemento más importante? /if the priority was to protect yourselves from the cold, why did you choose the map to be the most important element? 
Patricia: ((riéndose)) si yo se. (0.3) ummmm Pues empezamos con el mapa porque fue la primera opción que Alicia presentó.

Amelia decía que no, pero nosotras pensábamos que era el más importante en ese momento. /((laughing)) I know. (0.3) $\mathrm{mmmmm}$, well we started with the map because it was the first option that Alicia presented. Amelia said no, but we thought it was the most important in that moment/

Interviewer: ¿por qué la opinión de Amelia no fue tomada en cuenta?, ¿por qué no contemplaron la opción de la ropa? /why was not Amelia's opinion taken into account?, why did not you take into account the opinion about the clothes?/

Patricia: (0.4) Lo que pasa es que Amelia lo decía como con: miedo, luego se quedó callada. Y Alicia si explicó. Eso nos convenció. / (0.4) what happened was that Amelia said it like with fear, then she stayed in silence. Alicia did explain. That convinced us.

\section{INT-002-AM}

Interviewer: ¿cómo te ves como estudiante en la clase de inglés?/how do you see yourself as a student in English class?/

Amelia: ((mirándo al techo) ummmm como una persona que ha aprendido mucho pero falta me falta mucho. A veces pasiva a veces activa./((looking at the roof)) $\mathrm{mmmmmm}$ like a person that has learnt a lot but still I am missing things, many things. Sometimes passive sometimes active

Interviewer: ¿por qué?/why?/

Amelia: porque a veces no participo en clase porque no encuentro las palabras. Me falta vocabulario y a veces no confió mucho en mí, me da susto hablar!/because sometimes I do not participate in class because I do not find the words. I am missing vocabulary and sometimes I do not trust in myself, I am scared of talking.
Amelia positioned herself as insecure when talking, and she was recognized and repositioned by her partners in the same way. Discourses competing in this case showed me that there is an equivalent relationship between drawing on a determinant femininity discourse and holding the power in certain moments. In contrast, hesitating identity positions an individual as powerfulness.

\section{Discussion and conclusions}

Taking a look at the Colombian context, and being myself a Colombian teacher, I would claim that the majority of Colombian teachers are women which give us a particular identity as the ones who teach and care about others. What is more, these particular women under study are preschool teachers- in training. One may expect that the teacher-like behaviour was more than anticipated. However, it is worth to point out that not every one of the students performed this identity. Additionally, women talk has always been characterized as gentle, caring, maternal, and nice (Coates, 2004). Mary's interventions seem to emphasize on the differences rather than on helping others out. Opposite to what Davis (2003) found, Mary's discourse relegates other students, especially Katalina, to a lower position. More than solidarity, her teacher like behaviour looks for teacher's attention and recognition. Her assertiveness when speaking during the debate or correcting others is the way she uses to bring of being a woman (Coates, 2004). She does not show solidarity as such, instead, she tries to monitor others in order to show off her foreign language knowledge.

By raising her voice, or overlapping while others are speaking, Mary behaves as a subteacher who discursively uses these strategies to exercise power, to position herself as a good learner of English, which is plausible to say having into account the teacher's support that she receives when speaking. This assertion of 
power makes Katalina look as a less powerful one, because she is being prevented of talking and when she does, she is always criticized or corrected. Similarly, Alicia's intervention in extract 2 , shows a non-solidarity discourse. Instead of being a maternal or caring one, her use of miming and change in the tone of voice while simulating a disable person, let me reached that conclusion. Katalina claims (as it is shown in INT001-K) that she feels attacked and claims for her right to be wrong as a language learner (extract 3 ). Two assertions of power are experienced in here. Alicia tries to behave as a teacher by correcting Katalina, but at the same time, she has been challenged by Katalina's responses. Even though Alicia tries to position herself in a powerful position, Katalina resists and also performs a power and less powerful position almost at the same time.

Now, let us remember extract 4, where Mary is trying to position herself once again as a sub-teacher. Despite of the fact that she made use of the same strategies (correcting in this case) neither Alexandra nor the head-teacher acknowledge her discourse. Her attempt of being in a powerful position and showing up her knowledge of the second language was not successful this time because Alexandra and the head-teacher decided not to take it into account. In other words, they contested that position by ignoring her and not answering back which allowed Alexandra to participate, to get a response from the teacher and express herself in the foreign language.

Summarizing, by performing a femininity behaving as sub-teachers, Mary and Alicia could participate actively in the debate which, in practice, is considered as being a more- effective language learner. When a student remains in silence, or he/she does not participate much during class sessions, teachers as well as classmates tend to think that they are not good at English (in this case), or that he or she is not trying hard enough to learn. However, as I have shown, the reality is different. By alluding to gendered discourses, students can actually position themselves as more- effective language learners, even if they do not have the "appropriate knowledge" as when Mary and Alicia where correcting Katalina with the words "How do you mean culture", when the most appropriate utterance would have been "what does culture mean?"

There were other femininities that were identified during students' interactions. I named one of them Determinant Femininity. It was characterized by having a quality of deciding, leadership and imposing her point of view. This femininity gave Alicia the opportunity of performing really well during the second activity (extract 4, 5). Her opinions were always taken into account, while Amelia was performing a Hesitating Femininity. She tried to express her ideas in the foreign language, and she was doing very well. However her opinions were characterized by dubitation which projected the image that she was not sure about what she was saying, although she was doing it in English. Therefore her ideas were not as strong as Alicia's ideas. By drawing on the determinant femininity discourse, Alicia keeps her identity as a more- effective English learner, although she was breaking the mould, she is not a supportive woman.

Interestingly, in this activity, Mary did not perform as a sub-teacher, probably because there was not race for showing up her knowledge, due to the fact that the head-teacher was not part of this interaction. In extracts 4 and 5 , it is shown that Mary did not participate much, and when she did she was silenced by Alicia (extract 5). Mary's identity was shifted; she was positioned as a lesseffective language learner, although she was very successful in the previous activity. 


\section{Pedagogical implications and transformative actions}

These findings bring some pedagogical implications and transformative actions that deal firstly with acknowledging that learners of a language cannot be conceived of as abstract entities (Castañeda-Peña, 2008) but they are individuals that perform different identities and different gender identities in specific settings and moments. Therefore, English classes must be planned in a certain way that allows students to experience their identities as well as their strengths and weaknesses. Language teachers cannot separate students' ways of being claiming that the only thing that matters is the "accurate" production of language. Quite opposite, teachers should be aware of the possible variables that may affect one's learning process.

Secondly, when analyzing discourse, it is possible to identify specific moments where some students are more powerful than others. This is not something new. Power is always circulating among teachers and students. However, what is important to notice is how through discourse, teachers allow and back up students to perpetuate themselves in a power o less powerful position, preventing other students from learning or participating in classes.

Thirdly, what really matters when planning a lesson? In this particular case, as the teacher wanted an even group to do the oral debate, she forced Katalina to defend a position that she did not want to. This may affect Katalina's performance during the debate and reinforce Mary's and Alicia's positions, who could decide which position they wanted to defend. Would it have been different if Katalina were given the same opportunity? Would her performance and ideas during the debate have been more respected?

Fourthly, by discovering gendered identities, participants of this study could also understand in a clearer way how they are perceived by others, and at the same time how they perceived themselves. This is really important, especially for pre-service pre-school teachers, who are going to be in charge of teaching little children. They may be now more conscious about the way they talk, not only in terms of a foreign language communicative competence, but also about in terms of positioning and how this has an impact in their learning process. Therefore, they are now waiting to see how to plan their own lessons to provide equitable opportunities for their students, how to act and guide their own speeches as future teachers, and avoid labelling their students.

Lastly, as an in-service teacher and researcher, I consider that the results of this study helped me to understand better the way my teaching practice should be, and analyze and be critical about how I was doing it before. They also enriched my theoretical knowledge about discourse analysis as well as my experienced on how to use discourse analysis as a methodology to investigate classroom dynamics and conduct educational research.

\section{References}

Baxter, J. (2003). Positioning Gender in Discourse: A Feminist Methodology. Basingstoke: Palgrave McMillan

Birr, M. \& Lewis, C. (2007). Examining opportunities to learn literacy: the role of critical sociocultural literacy research. In Lewis, C., Enciso, P., \& Birr, E. (Eds). Reframing Sociocultural Research on Literacy: identity, agency and power (pp.15-48). New York: Routledge.

Butler, J. (1990). Gender Trouble: Feminism and the subversion of identity. New York: Routledge.

Castañeda-Peña, H. (2009). Masculinities and Femininities Go to Preschool. Bogotá: Pontificia Universidad Javeriana.

Castañeda-Peña, H. (2008a) Interwoven and Competing Gendered Discourse in a Pre-School EFL Lesson. In: Harrington, K. Litosseliti, L. Sauntson, H. \& Sun- 
derland, J. (Eds). Gender and Language Research Methodologies (pp.). Houndsmills, Basingstoke: Palgrave Macmillan.

Castañeda-Peña, H. (2008b) 'I said it!' 'I'm first!': Gender and language-learner identities. Colom. Appl. Linguist. J. 10. 112- 125.

Chouliaraki, L. and Fairclough, N. (1999). Discourse in Late Modernity: Rethinking Critical Discourse Analysis. Edinburgh: Edinburgh University Press.

Coates, J. (2004). Women, Men and Language. Harlow, UK: Pearson Logman.

Coulthard, R.M. and Sinclair, J.McH. (1975). Towards and Analysis of Discourse: The English Used by Teachers and Pupils (pp.) Oxford: Oxford University Press.

Fairclough, N. (1995). Critical Discourse Analysis: The critical study of language. Essex, UK: Longman.

Foucault, M. (1980). Power/Knowledge. Brighton: Harvester Press.

Foucault, M.(1972). Power/Knowledge: Selected interviews and other writings 1972-1977. New York: Pantheon Books

Francis, B. (1998). Oppositional positions: children's construction of gender in talk and role plays based on adult occupation. Educational Research. 40. (1), 31-43.

Harré, R. \& Langenhove, L. (1999). Positioning Theory. Oxford: Blackwell Publishers.

Johnson, S. (1997). Theorizing Language and Masculinity; a feminist perspective. Johnson, S. \& Meinhof
(Eds,) Language and Masculinity (pp. 8-26). Oxford: Blackwell .

Krashen, S. (1981). Second Language Acquisition and Second Language Learning. Oxford: Pergamon.

Litosseliti, L\& Sunderland, J. (2002). Gender identity and discourse analysis: discourse approaches to politics, society and culture. Amsterdam/Philadelphia: John Benjamins Publishing Company.

Mitchell, J.C.(1984) Typicality and the case study. In R. Ellen (ed). Ethnographic Research: a Guide to General Conduct. London: Academic Press.

Norton, B. (1997). Language identity and ownership of English. TESOL Quarterly, 31, 3 409-429.

Norton, B. (1995). Social identity, investment and language learning. TESOL Quarterly. 29 (1), 9-31

Orellana, M.F. (1996). Negotiating power through language in classroom., Im , Is meetings. In: Linguistics and Education. 8 (4) pp. 335- 365

Savignon, S. (1991). Communicative Language Teaching: State of art. I TESOL Quarterly. 25 pp. 261-278

Schegloff, E. (1997) Whose text? Whose context? In: Discourse and Society 8 (2): 165-187

Toohey, K. (2001). Disputes in child L2 learning. In: TESOL Quarterly. 35 pp. 257- 278

Walkerdine, V. (1998) Counting Girls Out: Girls and Mathematics. London: RoutledgeFalmer

Zimmerman, H. and West, C (1987). Sex Roles, Interruptions and Silences in Conversation. Newbury House.

THE AUTHOR

MARÍA XIMENA ROJAS is a full-time English teacher at San Buenaventura University, School of Education, LEBLI program. She holds a Bachelor degree from Universidad Pedagógica Nacional in Spanish and English Language Teaching and a M.A. in Applied Linguistic to Teaching English as a Foreign Language. She has been working at university level for 5 years teaching English, Research Methodology among others. Her research interests come from her experience in Discourse Analysis and Gender Issues in educational settings. Currently she is participating in TAEPE research group in the area of "Desafios Contemporáneos en la Enseñanza-Aprendizaje de Lenguas Extranjeras". 